\title{
Pemanfaatan Data Mining Dalam Memprediksi Kasus Positif Covid-19 Di Kota Palembang Menggunakan Algoritma K-Nearest Neighbors
}

\author{
Yulianita Purnamasari ${ }^{1}$, Yesi Novaria Kunang ${ }^{2}$ \\ 1,2Informatics Departement, Bina Darma University, Palembang, Indonesia \\ Email: ypsyuli5@gmail.com¹,yesi_kunang@.binadarma.ac.id²
}

\begin{abstract}
Covid-19 was first detected in Indonesia in early March 2020. The province of South Sumatra has more than 20,000 confirmed cases of Covid-19, 15,914 from Palembang City. The Covid-19 pandemic still shows no signs of ending. This can be seen from the increase in positive cases of Covid-19 every day. In making decisions on policies and decisions related to handling Covid-19, positive cases are still an important influence in this regard. Therefore, it focuses on predicting positive cases of Covid-19 in Palembang City. The data used in this study are data taken from the official website of the Palembang City Health Office as many as 153 data with 14 parameters. From 153 data, it is divided into 80\% training data and 20\% testing data. The variable used in this study is the daily number of confirmed cases of Covid-19 in Palembang City. KNN is used as a model to make predictions. From the research conducted, the RMSE results were 209,362. The results of this prediction can be used as input for research related to the prediction of positive cases of Covid19 in the city of Palembang.
\end{abstract}

Keywords: K-Nearest Neighbors, Covid-19,Prediction, RapidMiner, Knowladge Discovery in Database.

\section{PENDAHULUAN}

Coronavirus Disease 2019 (Covid-19) yaitu virus baru yang menyebabkan infeksi saluran pernafasan disebabkan oleh Severe Acute Respiratory Syndrome Coronavirus 2 (SARS-Cov-2) yang pertamakali teridentifikasi di Wuhan, China pada akhir tahun 2019. Virus ini berasal dari hewan yang dapat menular pada manusia dengan percikan air liur.[1] Covid-19 menyebar dengan sangat cepat, begitu juga penyebarannya di Indonesia. 


\section{Journal of Software Engineering Ampera}

Vol. 1, No. 2, June 2021 e-ISSN: 2775-2488

https://journal-computing.org/index.php/journal-sea/index

Covid-19 pertamakali terdeteksi di Indonesia pada awal bulan maret tahun 2020 [2] . Pada tanggal 2 maret 2020 terdeteksi 2 orang yang dinyatakan positif Covid-19 yang disebut sebagai kasus 1 dan kasus 2 [3].

Berdasarkan website resmi kawalCovid19.com jumlah pasien Covid-19 masih terus meningkat terlihat dari jumlah kasus terkonfirmasi pertanggal 06 juli 2021 tercatat 2.313.829 kasus terkonfirmasi Covid-19 di Indonesia. Provinsi Sumatera Selatan memiliki jumlah kasus terkonfirmasi Covid-19 lebih dari 20.000 pasien, 15.914 berasal dari Kota Palembang. Hal ini menjadikan Kota Palembang sebagai daerah yang paling 2 banyak terkonfirmasi Covid-19 di Provinsi Sumatera Selatan mengingat bahwa Kota Palembang merupakan Ibu Kota Dari Provinsi Sumatera Selatan.

Saat ini pemerintah sudah melakukan sebuah penekanan terhadap peningkatan jumlah kasus Covid-19 dengan memberlakukan pembatasan terhadap kegiatan masyarakat yang menyebabkan kerumunan dan memberikan vaksinasi terhadap masyarakat. Pada awal pandemi telah dilakukan berbagai kajian yang menunjukkan bahwa terjadinya penurunan dalam sektor ekonomi seperti menurunnya pertumbuhan ekonomi dan meningkatnya angka pengangguran dan kemiskinan [4]. Untuk mengatasi hal ini dapat dilakukan penyusunan strategi dalam menangani wabah Covid-19 yaitu dengan membuat sebuah prediksi kasus positif Covid-19 yang akan terjadi dalam beberapa waktu kedepan sehingga pihak yang bersangkutan dapat mengambil langkah-langkah dalam mencegah agar situasi tidak makin memburuk. Dalam data mining, peramalan digunakan sebagai alat bantu untuk memprediksi kemungkinan yang akan datang berdasarkan bukti-bukti temuan pada data. Data Mining adalah proses analisa data menggunakan perangkat lunak untuk menemukan pola atau aturan tertentu dari sejumlah data dalam jumlah yang besar yang diharapkan dapat menemukan pengetahuan guna mendukung keputusan [5]

Dalam pembuatan Prediksi kasus positif Covid-19 ini diperlukan data kasus Covid-19 terdahulu dan metode yang mampu melakukan prediksi seperti metode K-Nearest Neighbors. Algoritma KNN merupakan algoritma yang sederhana, yaitu bekerja berdasarkan jarak terpendek dari query instance ke training sample untuk menentukan ketetanggaannya [6]. Algoritma KNN adalah sebuah metode untuk meakukan klasifikasi terhadap objek berdasarkan data pembelajaran yang jaraknya paling dekat dengan objek tersebut [7]. 


\section{Journal of Software Engineering Ampera}

Vol. 1, No. 2, June 2021 e-ISSN: 2775-2488

https://journal-computing.org/index.php/journal-sea/index

\section{METODOLOGI PENELITIAN}

Metode yang digunakan dalam penelitian ini adalah menggunakan tahapan Knowladge Discovery in Database (KDD) yang terdiri dari beberapa tahapan, yaitu data selection, preprocessing, transformation, data mining dan evaluasion.

\subsection{Bahan Penelitian}

Dalam penelitian ini bahan yang digunakan untuk kemudian diolah dan menjadi acuan adalah data time series atau deret waktu berupa data kasus Covid-19 di Kota Palembang dari 1 Agustus 2020 hingga 31 Agustus 2021 yang didapatkan dari situs resmi Dinas Kesehatan Kota Palembang.

\subsection{Tahapan Penelitian}

Tahapan yang dilakukan dalam penelitian ini yaitu :

1. Tahapan pertama yaitu tahapan persiapan dimana pada tahapan ini ditentukan objek yang akan diteliti, Batasan dan penyusunan rencana penelitian.

2. Tinjauan kepustakaan yaitu melakukan telaah dan studi literatur mengenai suatu prediksi yang berhubungan dengan penelitian.

3. Tahapan ketiga yaitu tahap pengumpulan data. Data didapatkan dari situs resmi Dinas Kesehatan Kota Palembang (https://dinkes.palembang.go.id).

4. Tahap keempat yaitu pengolahan data mining. Data yang sudah dikumpulkan diolah sesuai dengan tahapan Knowledge Discovery in Database (KDD).

5. Tahapan kelima yaitu hasil dan pembahasan. Pada tahapan ini menjelaskan mengenai hasil dari proses data mining yang dilakukan dengan menggunakan metode $K$-Nearest Neighbors.

6. Tahapan terakhir yaitu kesimpulan dan saran. Membuat kesimpulan dari hasil penelitian yang dilakukan dan memberikan saran kepada instansi terkait agar dapat dapat memberikan sebuah keputusan yang tepat.

\section{HASIL DAN PEMBAHASAN}

\subsection{Data Selection}

Tahapan pertama dalam penelitian ini adalah data selection. Data yang digunakan dalam penelitian ini yaitu data kasus Covid-19 di Kota Palembang dari 1 April 2021 hingga 31 Agustus 2021 yang berasal dari situs resmi Dinas 


\section{Journal of Software Engineering Ampera}

Vol. 1, No. 2, June 2021 e-ISSN: 2775-2488

https://journal-computing.org/index.php/journal-sea/index

Kesehatan Kota Palembang. Setelah dilakukan seleksi data, atribut yang digunakan dalam memprediksi kasus positif Covid-19 di Kota Palembang yaitu Tanggal dan Kasus Konfirmasi Baru. Contoh data tersebut dapat dilihat pada Gambar 1 :

\begin{tabular}{|c|r|c|c|c|}
\hline \multicolumn{2}{|c|}{ A } & B & B & C \\
\cline { 1 - 2 } 1 & No & Tanggal & Kasus Konfirmasi Baru & \\
\hline 2 & 1 & 01 April 2021 & 51 \\
\hline 3 & 2 & 02 April 2021 & 26 \\
\hline 4 & 3 & 03 April 2021 & 18 \\
\hline 5 & 4 & 04 April 2021 & 32 \\
\hline 6 & 5 & 05 April 2021 & 33 \\
\hline 7 & 6 & 06 April 2021 & 28 \\
\hline 8 & 7 & 07 April 2021 & 37 \\
\hline 9 & 8 & 08 April 2021 & 42 \\
\hline 10 & 9 & 09 April 2021 & 35 \\
\hline 11 & 10 & 10 April 2021 & 52 \\
\hline 12 & 11 & 11 April 2021 & 39 \\
\hline 13 & 12 & 12 April 2021 & 37 \\
\hline 14 & 13 & 13 April 2021 & 29 \\
\hline 15 & 14 & 14 April 2021 & 31 \\
\hline 16 & 15 & 15 April 2021 & 40 \\
\hline
\end{tabular}

Gambar 1. Hasil Seleksi Data

\subsection{Pre-processing \& Cleaning}

Tahapan pre-processing merupakan proses yang dilakukan untuk membuat data mentah menjadi data yang berkualitas atau data yang dapat digunakan dalam proses data mining. Pada tahapan ini pre-processing dilakukan untuk mengelompokkan data berdasarkan tanggal dan bulan agar mempermudah dalam perhitungan prediksi. Contoh datanya dapat dilihat pada Gambar 2.

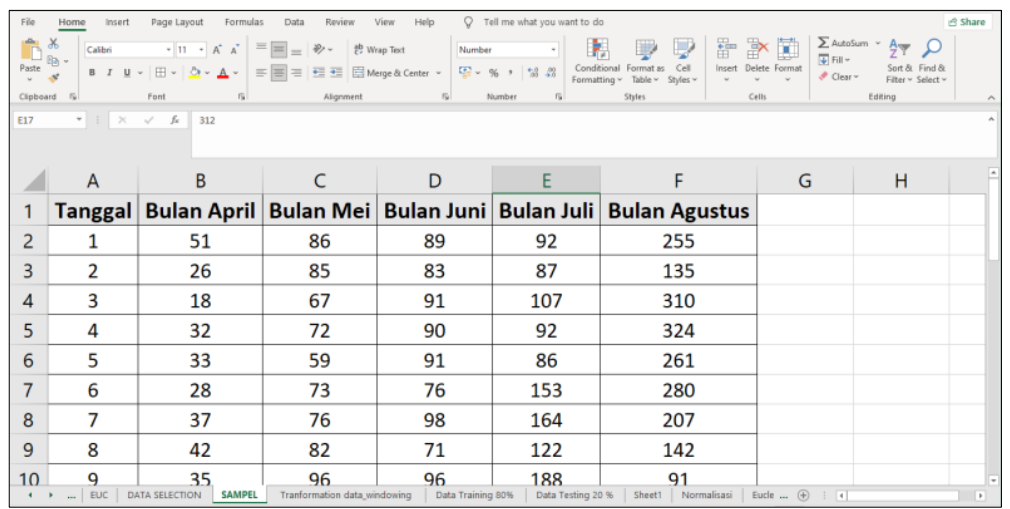

Gambar 2. Hasil Pre-Processing

\subsection{Transformation}

Proses transformasi data merupakan proses mengubah bentuk data menjadi data yang sesuai untuk digunakan dalam proses data mining. Data hasil 


\section{Journal of Software Engineering Ampera}

Vol. 1, No. 2, June 2021 e-ISSN: 2775-2488

https://journal-computing.org/index.php/journal-sea/index

tahapan sebelumnya digunakan pada tahapan ini sebagai data training dan data testing. Pada tahapan ini, data disusun dengan berderet berdasarkan urutan kemudian diolah dengan menggunakan metode sliding window dengan menggunakan RapidMiner agar sesuai dengan kebutuhan bahan penelitian yang dapat dilihat pada Gamber 3. Data training yang digunakan dalam penelitian ini adalah $80 \%$ dari data 5 bulan sebelumnya. Contohnya yaitu pada Gambar 4. Sedangkan untuk data testing diambil 20\% dari pembagian data testing dan data training. Contoh datanya dapat dilihat pada Gambar 5.

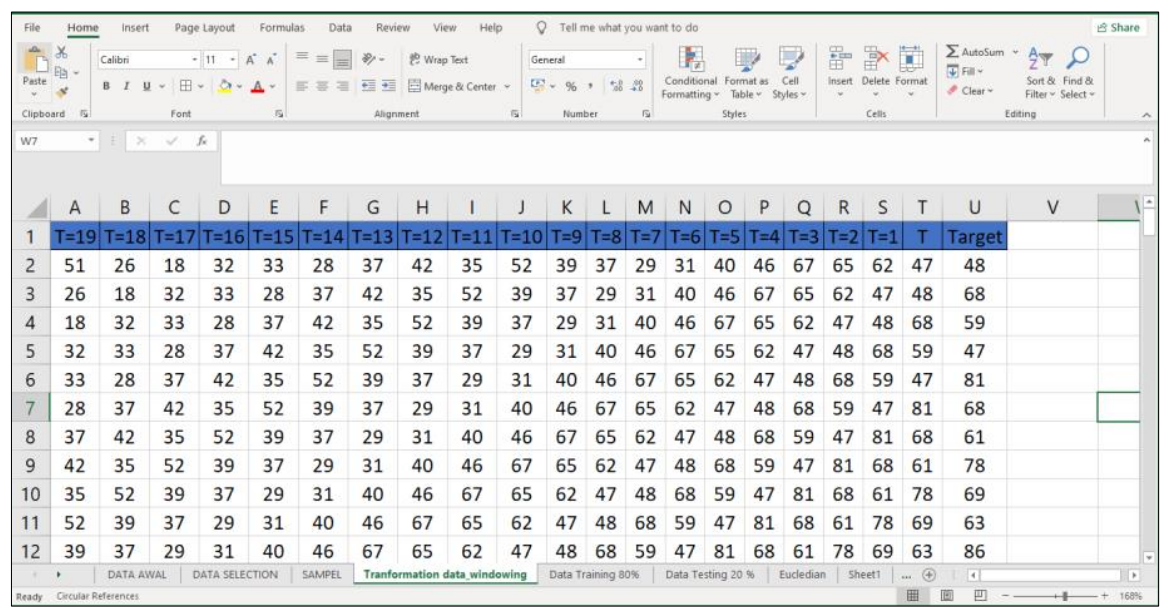

Gambar 3. Data Hasil Transformasi

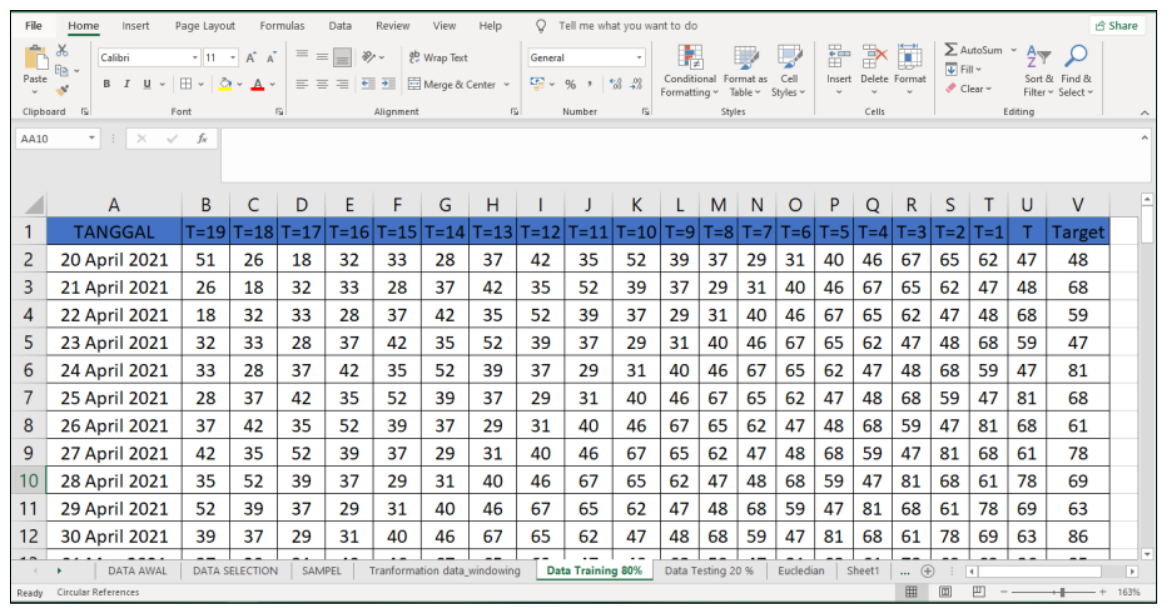

Gambar 4. Data Training 


\section{Journal of Software Engineering Ampera}

Vol. 1, No. 2, June 2021 e-ISSN: 2775-2488

https://journal-computing.org/index.php/journal-sea/index

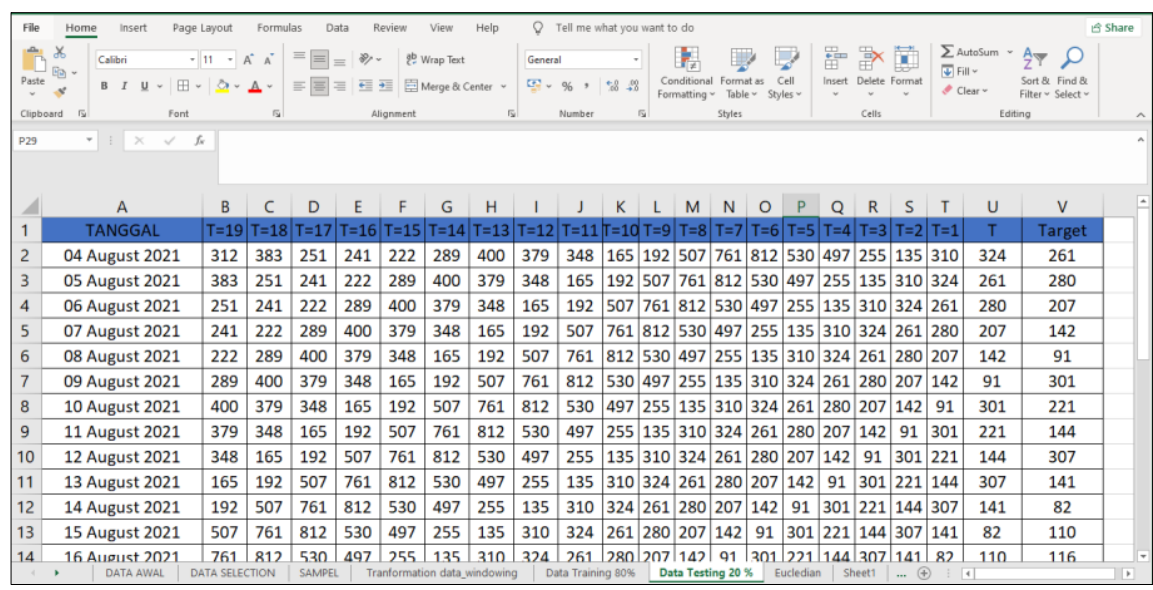

Gambar 5. Data Testing

\subsection{K-Nearest Neighbors}

Pada tahapan ini yang dilakukan adalah menentukan parameter $k$. Tidak ada peraturan baku dalam penentuan parameter $k$ maka $k$ yang akan digunakan dalam penelitian ini adalah parameter $k=5$. Kemudian menghitung jarak terdekat dari seluruh data training pada tahap transformation dengan menggunakan rumus perhitungan euclidean distance [8].

$$
d_{(x, y)}=\sqrt{\sum_{i=1}^{n}(x i-y i)^{2}}
$$

\section{Keterangan:}

$$
\begin{array}{ll}
\mathrm{d} & \text { : jarak } \\
\mathrm{n} & \text { : banyaknya jumlah data } \\
\mathrm{i} & \text { : variabel data } \\
\mathrm{xi} & \text { : sampel data / data training } \\
\text { yi } & \text { : data uji / testing }
\end{array}
$$

Mengurutkan data hasil perhitungan berdasarkan jarak yang paling dekat sampai dengan jarak yang paling jauh yang dapat dilihat pada Gambar 6 . 


\section{Journal of Software Engineering Ampera}

Vol. 1, No. 2, June 2021 e-ISSN: 2775-2488

https://journal-computing.org/index.php/journal-sea/index

\begin{tabular}{|c|c|c|c|}
\hline 4 & A & B & C \\
\hline 1 & No & EUCLIDEAN & rank \\
\hline 2 & $\mathrm{D} 1,2$ & 48,9182992 & 1 \\
\hline 3 & $\mathrm{D} 1,3$ & 66,9402719 & 2 \\
\hline 4 & $\mathrm{D} 1,4$ & 69,5701085 & 3 \\
\hline 5 & $\mathrm{D} 1,5$ & 73,6274405 & 4 \\
\hline 6 & $\mathrm{D} 1,8$ & 74,3303437 & 5 \\
\hline 7 & D1,7 & 78,4538081 & 6 \\
\hline 8 & $\mathrm{D} 1,9$ & 80,8022277 & 7 \\
\hline 9 & $\mathrm{D} 1,6$ & 81,9939022 & 8 \\
\hline 10 & D1,10 & 83,156479 & 9 \\
\hline 11 & D1,11 & 88,4081444 & 10 \\
\hline 12 & D1,12 & 101,434708 & 11 \\
\hline 13 & $\mathrm{D} 1,13$ & 113,379892 & 12 \\
\hline 14 & D1,14 & 117,639279 & 13 \\
\hline 15 & D1,15 & 122,92274 & 14 \\
\hline 16 & D1,16 & 124,935984 & 15 \\
\hline 4 & , $\quad \ldots$ & \multicolumn{2}{|c|}{ DATA SELECTION } \\
\hline
\end{tabular}

Gambar 6. Hasil Perhitungan Euclidean

Tahapan selanjutnya yaitu menentukan kelompok label mayoritas dari $k$ tetangga terdekat. Pada penelitian ini nilai $k=5$ maka diambil 5 jarak terkecil yaitu $d_{1,2}, d_{1,3}, d_{1,4}, d_{1,5}, d_{1,8}$. Dengan menggunakan kategori Nearest Neighbors yang paling mayoritas maka dapat diprediksikan jumlah kasus pada hari berikutnya.

\subsection{Implementasi RapidMiner}

RapidMiner merupakan suatu tools yang digunakan untuk melakukan analisis data mining. RapidMiner merupakan salah satu software pengolahan dataset untuk mencari pola data sesuai dengan tujuan dari pengolahan data tersebut. RapidMiner mengekstrak pola-pola dari data set yang besar degan mengkombinasikan metode statistika, kecerdasan buatan dan database [9].

\subsubsection{Prediksi Algoritma K-Nearest Neighbors}

Proses prediksi dengan algoritma K-NN menggunakan tool RapidMiner bisa dilihat pada Gambar 7. Tahapan awal adalah proses pembacaan data dari tabel excel data training. Data training sendiri merupakan data yang sudah diolah dari proses transformation yang terdiri dari 20 fitur. Contoh data training yang dibaca bisa dilihat pada Gambar 8. Tahapan selanjutnya yaitu proses pembacaan data dari tabel excel data testing. Contoh pembacaan data testing dapat dilihat pada Gambar 9. Kemudian menggunakan algoritma K-NN sebagai metode prediksi dan menetukan nilai $k$ yaitu $k=5$ yang dapat dilihat 


\section{Journal of Software Engineering Ampera}

Vol. 1, No. 2, June 2021 e-ISSN: 2775-2488

https://journal-computing.org/index.php/journal-sea/index

pada Gambar 10. Tahapan selanjutnya adalah menghubungkan operator K-NN dan Read Excel 2 dengan operator apply model untuk menggabungkan operator K-NN dengan read excel 2 menjadi satu kesatuan model dan operator performance untuk mengetahui kinerja dari model K-NN yang terbentuk.

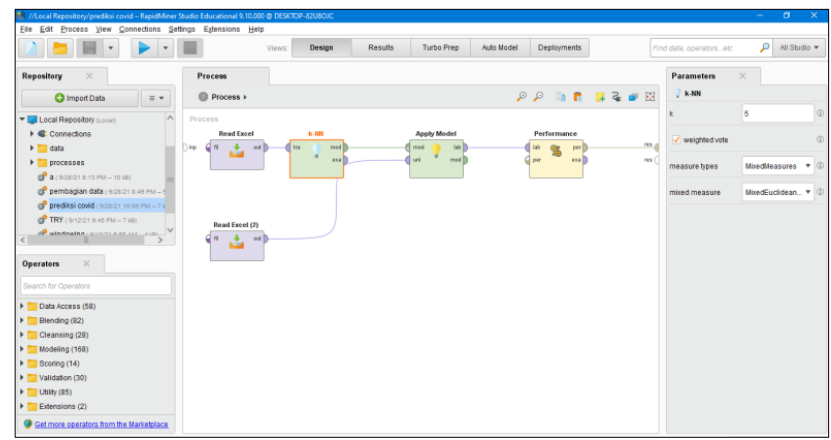

Gambar 7. Model prediksi K-NN

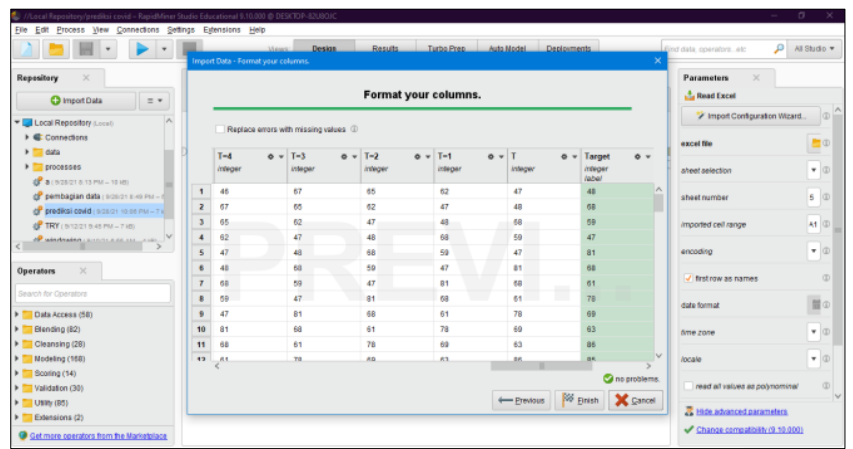

Gambar 8. Import Data Training

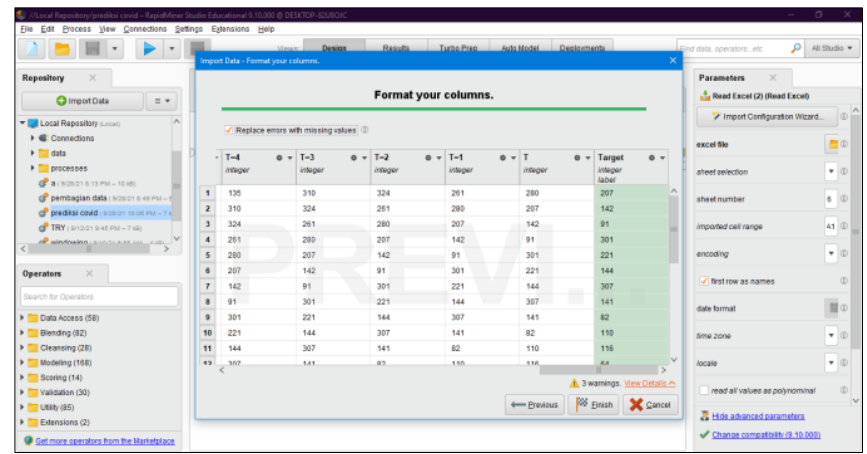

Gambar 9. Import Data Testing 


\section{Journal of Software Engineering Ampera}

Vol. 1, No. 2, June 2021 e-ISSN: 2775-2488

https://journal-computing.org/index.php/journal-sea/index

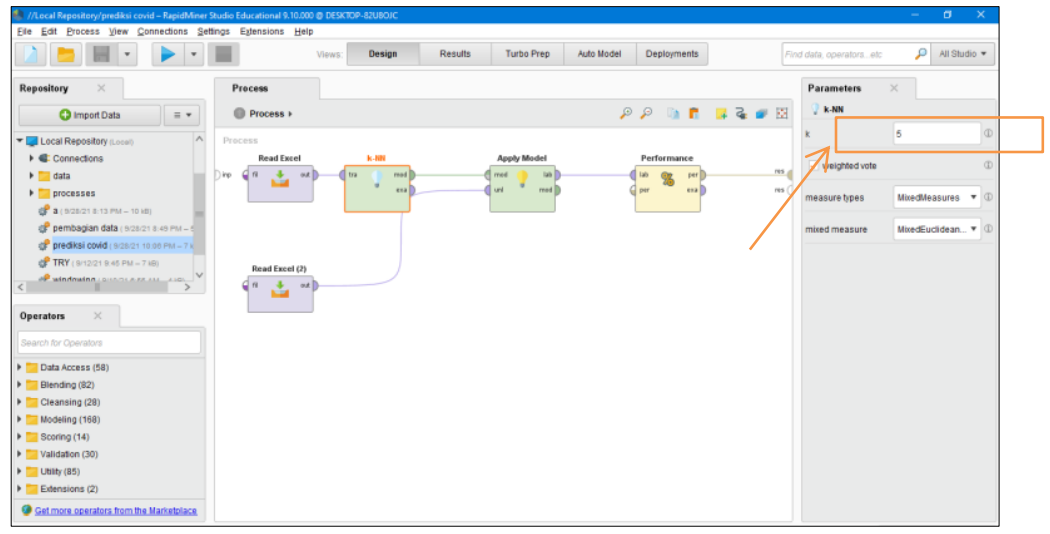

Gambar 10. Menentukan Nilai K

\subsubsection{Hasil Algoritma K-Nearest Neighbors}

Hasil dari Proses prediksi dengan algoritma K-NN menggunakan tool RapidMiner yang dimana setelah semua operator dihubungkan kemudian klik icon play, maka akan tampil sebuah tab result yang isinya merupakan sebuah prediksi dari seluruh data yang memenuhi nilai $k=5$ dengan data training $80 \%$ dan data testing $20 \%$, yang dapat dilihat pada Gambar 11. hasil prediksi dapat dilihat pada bagian prediction(Target), sedangkan bagian-bagian yang lain merupakan data harian secara real.

\begin{tabular}{|c|c|c|c|c|c|c|c|c|c|}
\hline Open in & Turbo Prep & 觓 Auto Model & & & & \multicolumn{2}{|c|}{ Filter (27 / 27 examples): } & all & $\checkmark$ \\
\hline Row No. & TANGGAL & Target & prediction(T... & $\mathrm{T}=19$ & $\mathrm{~T}=18$ & $T=17$ & $\mathrm{~T}=16$ & $T=15$ & $T=14$ \\
\hline 13 & Aug 18,2021 & 161 & 87.578 & 530 & 497 & 255 & 135 & 310 & $324 \wedge$ \\
\hline 14 & Aug 19, 2021 & 109 & 116.500 & 497 & 255 & 135 & 310 & 324 & 261 \\
\hline 15 & Aug 20,2021 & 119 & 90.578 & 255 & 135 & 310 & 324 & 261 & 280 \\
\hline 16 & Aug 21, 2021 & 45 & 87.225 & 135 & 310 & 324 & 261 & 280 & 207 \\
\hline 17 & Aug 22, 2021 & 240 & 95.559 & 310 & 324 & 261 & 280 & 207 & 142 \\
\hline 18 & Aug 23,2021 & 122 & 114.084 & 324 & 261 & 280 & 207 & 142 & 91 \\
\hline 19 & Aug 24, 2021 & 103 & 108.846 & 261 & 280 & 207 & 142 & 91 & 301 \\
\hline 20 & Aug 25, 2021 & 88 & 116.477 & 280 & 207 & 142 & 91 & 301 & 221 \\
\hline 21 & Aug 26, 2021 & 79 & 86.397 & 207 & 142 & 91 & 301 & 221 & 144 \\
\hline 22 & Aug 27,2021 & 58 & 83.407 & 142 & 91 & 301 & 221 & 144 & 307 \\
\hline 23 & Aug 28,2021 & 34 & 91.175 & 91 & 301 & 221 & 144 & 307 & 141 \\
\hline 24 & Aug 29,2021 & 35 & 85.198 & 301 & 221 & 144 & 307 & 141 & 82 \\
\hline 25 & Aug 30,2021 & 52 & 88.207 & 221 & 144 & 307 & 141 & 82 & 110 \\
\hline 26 & Aug 31, 2021 & ? & 81.641 & 144 & 307 & 141 & 82 & 110 & 116 \\
\hline 27 & Sep 1, 2021 & ? & 79.577 & 307 & 141 & 82 & 110 & 116 & $64 \mathrm{v}$ \\
\hline
\end{tabular}

Gambar 11. Hasil Prediksi

Prediksi ini juga ditampilkan dalam bentuk visualisasi yang dapat dilihat pada Gambar 12. Kurva yang berwarna merah merupakan data sebenarnya dan kurva warna hijau merupakan hasil dari prediksi. adanya tidak keseimbangan 


\section{Journal of Software Engineering Ampera}

Vol. 1, No. 2, June 2021 e-ISSN: 2775-2488

https://journal-computing.org/index.php/journal-sea/index

antara data target dan data hasil prediksi. Hal ini dapat terjadi karena adanya beberapa faktor yang dapat mempengaruhi diantaranya faktor dari kebijakan pemerintahan pusat dan pemerintahan daerah yang berbeda-beda pada tiap daerahnya. Sebagai contoh di Kota Pelembang, pemerintahan Kota Palembang sudah menerapkan yang namanya penerapan pembatasan kegiatan masyarakat (PPKM). Faktor ini dapat mendorong adanya penurunan angka dari kasus positif covid-19 itu sendiri karena dengan adanya PPKM kegiatan berkerumun yang akan menyebabkan penyebaran virus akan menjadi sangat terbatas. Ada juga faktor lain yang dapat mempengaruhi penurunan kasus covid-19 yaitu vaksinasi. Faktor lainnya yang dapat juga menyebabkan tidak seimbangnya data target dan hasil prediksi yaitu kurangnya data training dan sedikitnya fitur-fitur yang digunakan dalam proses prediksi seperti fitur level dari PPKM dan jumlah yang sudah melakukan vaksinasi.

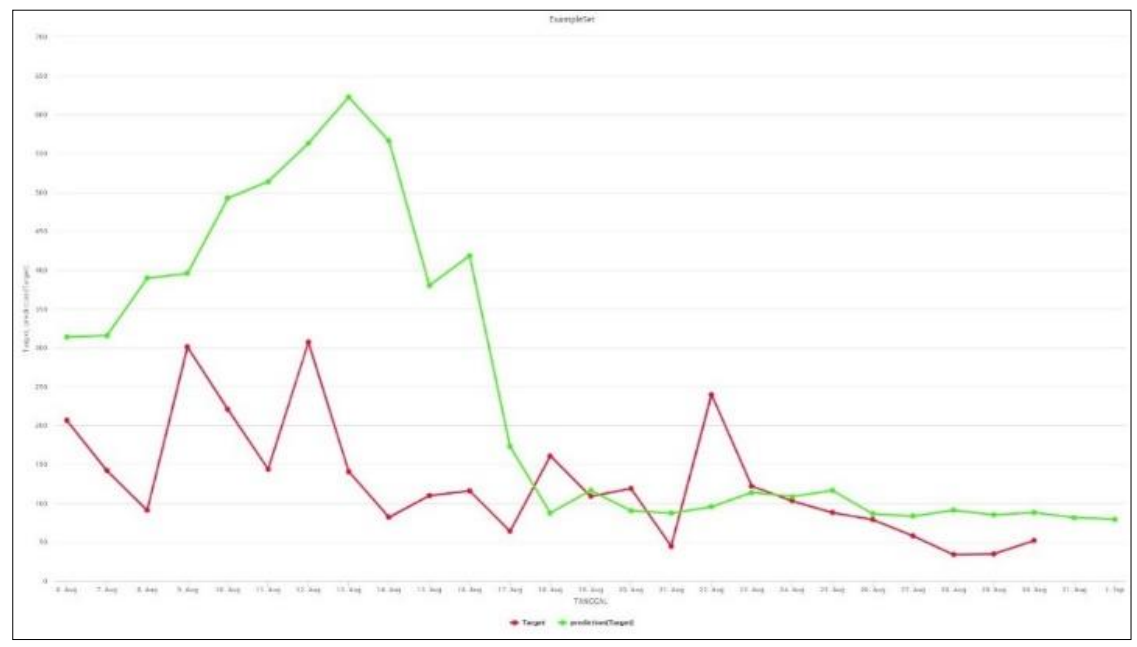

Gambar 12. Visualisasi Prediksi

\section{KESIMPULAN}

Berdasarkan dari penelitian yang dilakukan, dapat disimpulkan bahwa Algoritma K-Nearest Neighbors dapat digunakan dalam melakukan prediksi terhadap kasus positif Covid-19 di Kota Palembang, dengan melalui beberapa proses yaitu proses pengubahan dataset kedalam bentuk yang sesuai untuk proses data mining, menghitung jarak antar data training dan menghitung nilai prediksi berdasarkan nilai $k$ tetangga terdekat. Hasil prediksi juga ditampilkan dalam bentuk visualisasi berupa grafik plot yang telah didapat 


\section{Journal of Software Engineering Ampera}

Vol. 1, No. 2, June 2021 e-ISSN: 2775-2488

https://journal-computing.org/index.php/journal-sea/index

dengan menggunakan RapidMiner untuk mempermudah dalam menampilkan hasil prediksi. Adapun hasil dari evaluasi perhitungan algoritma K-Nearest Neighbors masih cukup sederhana dengan $k=5$ menghasilkan RMSE sebesar 209.362.

\section{DAFTAR PUSTAKA}

[1] Anggraini, S., Akbar, M., Wijaya, A., Syaputra, H., \& Sobri, M. (2021). Klasifikasi Gejala Penyakit Coronavirus Disease 19 (COVID-19) Menggunakan Machine Learning. Journal of Software Engineering Ampera, 2(1), 57-68.

[2] Susilo, A. et al. (2020) 'Coronavirus Disease 2019: Tinjauan Literatur Terkini', Jurnal Penyakit Dalam Indonesia, 7(1), p. 45. doi: 10.7454/jpdi.v7i1.415.

[3] Arianto, D. and Noviyanti Pui (2020) 'PREDIKSI KASUS COVID-19 DI INDONESIA MENGGUNAKAN METODE BACKPROPAGATION DAN FUZZY TSUKAMOTO'. doi: 10.13140/RG.2.2.34286.02885.

[4] Joyosemito, I. S. and Nasir, N. M. (2021) 'Pendekatan Pemodelan Matematika Dinamis Dalam Analisis Prediksi COVID-19 Sebagai Masukan Kebijakan Pemerintah Indonesia', p. 16.

[5] Andri, A., Kunang, Y. N., \& Murniati, S. (2015, July). Implementasi Teknik Data Mining Untuk Memprediksi Tingkat Kelulusan Mahasiswa Pada Universitas Bina Darma Palembang. In Seminar Nasional Informatika (SEMNASIF) (Vol. 1, No. 1).

[6] Mulyati, S., Husein, S. M. and Ramdhan, R. (2020) 'RANCANG BANGUN APLIKASI DATA MINING PREDIKSI KELULUSAN UJIAN NASIONAL MENGGUNAKAN ALGORITMA (KNN) K-NEAREST NEIGHBOR DENGAN METODE EUCLIDEAN DISTANCE PADA SMPN 2 PAGEDANGAN', JIKA (Jurnal Informatika), 4(1), p. 65. doi: 10.31000/jika.v4i1.2288

[7] Kurniawan, Y. I., \& Barokah, T. I. (2020). Klasifikasi Penentuan Pengajuan Kartu Kredit Menggunakan K-Nearest Neighbor. Jurnal Ilmiah Matrik, 22(1), 73-82.

[8] Madyaningrum, N.A. (2019b) 'ANALISA PREDIKSI KEKAMBUHAN KANKER PAYUDARA DENGAN MENGGUNAKAN ALGORITMA K-NEAREST NEIGHBOR', p. 6.

[9] Sumarlin, S., \& Anggraini, D. (2019). IMPLEMENTASI K-NEAREST NEIGHBORD PADA RAPIDMINER UNTUK PREDIKSI KELULUSAN MAHASISWA. High Education of Organization Archive Quality: Jurnal Teknologi Informasi, 10(1), 35-41. 